\title{
The Toxic Role of Alpha-haemolysin in the Pathogenesis of Experimental Escherichia coli Infection in Mice
}

\author{
By H. WILliams SMITH* and M. B. HUGGins \\ Houghton Poultry Research Station, Houghton, Huntingdon, Cambridgeshire PE17 2DA, UK
}

(Received 12 July 1984 ; revised 7 September 1984)

\begin{abstract}
Filtrates from strains of Escherichia coli possessing plasmid-cloned haemolysin (Hly) genes and from strains possessing 'wild' Hly plasmids were lethal for mice on intravenous inoculation; similar doses of preparations from derivatives of these strains in which the Hly genes had been rendered non-functional or which did not possess the 'wild' plasmids were not. Live cultures of both kinds of $\mathrm{Hly}^{+}$strain usually had a lower lethal dose for mice on intraperitoneal inoculation than the corresponding $\mathrm{Hly}^{-}$forms. Mice that had been inoculated with $\mathrm{Hly}^{+}$forms had shorter survival times and lower numbers of organisms in peritoneal washings, lungs and blood at point of death than mice that had been inoculated with the corresponding $\mathrm{Hly}^{-}$forms; this was also so for mice pre-treated with $\mathrm{FeSO}_{4}$, a procedure which rendered mice equally susceptible to the lethal effects of the $\mathrm{Hly}^{+}$and $\mathrm{Hly}^{-}$forms of a strain. In $\mathrm{FeSO}_{4}$-treated mice the numbers of organisms in the tissues of those dying from infection with $\mathrm{Hly}^{+}$organisms were no higher than they were at the same time after inoculation in others given the corresponding $\mathrm{Hly}^{-}$forms; before mice of the latter category died the numbers of organisms in their tissues increased greatly. The clinical and pathological signs exhibited by mice inoculated with $\mathrm{Hly}^{+}$organisms, but not with $\mathrm{Hly}^{-}$organisms, resembled those exhibited by mice inoculated with bacteria-free haemolysin preparations. These results suggest that haemolysin played a significant role in the pathogenesis of the disease produced by the $\mathrm{Hly}^{+}$organisms by having a direct toxic action on the host.
\end{abstract}

\section{INTRODUCTION}

Following their discovery of the transferable nature of the haemolysin (Hly) genes in many alpha-haemolytic strains of Escherichia coli, Smith \& Halls (1967) demonstrated by intravenous (i.v.) inoculation of bacteria-free fluids of cultures of laboratory-constructed $E$. coli strains differing in the presence or absence of the Hly plasmid that haemolysin was toxic for mice. Using this and other approaches, several workers have produced evidence that the haemolysin is toxic to cultured animal and human fibroblasts (Chaturvedi et al., 1969; Cooke \& Ewins, 1975; Cavalieri \& Snyder, 1982a) and rabbit and human leucocytes (Emödy et al., 1980; Cavalieri \& Snyder, 1982b, $c$; Gadeberg et al., 1983). It has been shown in several animal models that viable $\mathrm{Hly}^{+}$forms of a strain are more virulent than $\mathrm{Hly}^{-}$forms (Fried et al., 1971; Smith \& Linggood, 1971: Kétyi et al., 1978; Emödy et al., 1980; van den Bosch et al., 1981, 1982; Linggood \& Ingram, 1982; Waalwijk et al., 1982). Smith \& Linggood (1971) mainly studied $\mathrm{Hly}^{+}$and $\mathrm{Hly}^{-}$ forms of an $\mathrm{O} 141: \mathrm{K} 85,88$ porcine enteropathogenic E. colistrain, called P5. They found that the $\mathrm{Hly}{ }^{+}$forms were more lethal for mice by intraperitoneal (i.p.) inoculation than the corresponding Hly- forms. This observation with P5 was confirmed by Linggood \& Ingram (1982). These workers, however, reported that such toxicity as they observed in mice inoculated with bacteriafree preparations of cultures of $E$. coli $\mathrm{K} 12$ to which Hly plasmids had been transferred did not correlate with the haemolysin titres of their preparations. In fact, their subsequent experiments

Ahbreviations: i.p., intraperitoneal(ly); i.v., intravenous(ly). 
with derivatives of P5 led them to the conclusion that haemolysin enhanced virulence by enabling $E$. coli to obtain iron necessary for growth by lysis of erythrocytes in infected mice. Rapid bacterial proliferation then occurred leading to death of the animals. Their main evidence for this role for haemolysin was the finding that $\mathrm{Hly}^{-}$organisms multiplied to the same rapid extent as $\mathrm{Hly}^{+}$organisms of the same strain when both kinds of organisms were inoculated together into mice or when the $\mathrm{Hly}^{-}$organisms were inoculated with haemolysin or iron but not when they were inoculated alone. Additional evidence was that the presence of anti-haemolysin protected mice against death by inhibiting the proliferation of normally virulent haemolytic organisms.

Because techniques such as plasmid manipulation had been employed to obtain the strains used in many of the above-mentioned experiments, they would be expected to yield more reliable information than would a comparison of wild haemolytic and non-haemolytic strains of E. coli. Nevertheless, the possibility still exists that mutants of a strain that had acquired or lost Hly genes might concurrently have acquired or lost other genes, genes that might themselves influence virulence. Welch et al. (1981) overcame this problem by comparing the virulence of an E. coli strain possessing a plasmid in which Hly genes had been cloned with that of an ampicillin resistance insertional plasmid mutant of that strain which no longer conferred the haemolytic phenotype; they found that the $\mathrm{Hly}^{+}$parent strain, inoculated i.p., was more virulent for rats than the mutant. Using somewhat similar approaches but in different animal models, Hacker $e t$ al. (1983), Waalwijk \& de Graaff (1983) and Waalwijk et al. (1983) obtained results similar to those of Welch et al. (1981). In addition, Waalwijk et al. (1983), using a mouse haematogenous pyelonephritis model, produced evidence suggesting, as Linggood \& Ingram (1982) had done, that haemolysin enhances virulence mainly by increasing the amount of available iron.

Because Dr Welch kindly made his strains available to us we decided to use them and some of our strains containing 'wild' Hly plasmids to re-investigate the toxicity of haemolysin for mice and the role that haemolysin plays in the pathogenesis of experimentally produced generalized E. coli infections in mice.

\section{METHODS}

Bacterial strains. E. coli strains provided by Dr Welch (Welch et al., 1981), were as follows. WAF107 was a derivative of a strain $\mathrm{J} 198$, containing plasmid pSF4000 which had been constructed by insertion of an $11.7 \mathrm{~kb}$ chromosomal restriction endonuclease fragment encoding haemolysin into a plasmid vector. WAF108 was WAF 107 containing a $\mathrm{Tn} l$ insertional mutant of its plasmid which no longer conferred the haemolysin phenotype. WAF 111 was $\mathrm{J} 198$ containing plasmid pAN202-312 in which the Hly determinants of a ' wild' plasmid had been cloned by Goebel \& Hedgpeth (1982). Other E. coli strains employed were either porcine enteropathogens (prefix P), whose haemolysin genes were located in 'wild' plasmids, plasmid-free (Pla') derivatives of them and nonhaemolytic strains to which the Hly plasmids had been transferred; P5, the O141:K85,88 strain previously studied by Smith \& Linggood (1971) and Linggood \& Ingram (1982) was used in its $88^{-}, \mathrm{Col}^{-}$form. The non-haemolytic strains included spontaneous antibiotic-resistant mutants of a prototrophic K12 strain; of strain $\mathrm{H} 209$ $(\mathrm{O} 9: \mathrm{K} 31: \mathrm{H} 4)$, that had been isolated from the faeces of a healthy human being; of strain $\mathrm{MW}(\mathrm{O} 18: \mathrm{K} 1: \mathrm{H} 7)$, that had caused meningitis in a baby (Smith \& Huggins, 1980); and strain B188 (O78), that had caused generalized infection in a calf. Originally, MW and B 188 possessed ColV plasmids but $\mathrm{ColV}^{-}$derivatives were used in these studies because $\mathrm{Hly}$ plasmids could not be transferred to the $\mathrm{ColV}^{+}$forms. The particular plasmid inserted in $\mathrm{MW}$ had been mobilized by transfer factor F from P102, a Tra- O141:K85 strain, transferred to MW and then F eliminated by treatment with sodium lauryl sulphate. The methods of transferring Hly plasmids and of isolating $\mathrm{Pla}^{-}$mutants from $\mathrm{Hly}^{+}$strains were those of Smith \& Linggood (1971).

Culture media and cultural conditions. Unless stated, all inoculated culture media were incubated at $37^{\circ} \mathrm{C}$ for $24 \mathrm{~h}$, liquid media, except when used for plasmid transfer, being shaken in a water bath (100 r.p.m.). Broth cultures consisting of organisms grown in $10 \mathrm{ml}$ nutrient broth, Oxoid No. 2 (CM67), contained 1.5-3.0 $\times 10^{9}$ viable organisms $\mathrm{ml}^{-1}$. Those of $\mathrm{Hly}^{+}$organisms contained very little or no cell-free haemolysin. Alkaline extract broth, used for haemolysin production, was prepared according to the method of Smith (1963). Chloramphenicol $\left(20 \mu \mathrm{g} \mathrm{ml}^{-1}\right)$ was added to all media used for growing strains WAF107, WAF108 and WAF111 because their plasmids, which contained genes for chloramphenicol resistance, were unstable.

Haemolysin preparations. Alkaline extract broth $(70 \mathrm{ml})$ in $250 \mathrm{ml}$ Erlenmeyer flasks was inoculated with $7 \mathrm{ml}$ of a broth culture of $E$. coli and incubated for $3 \mathrm{~h}$. It was then centrifuged at $6000 \mathrm{~g}$ for $30 \mathrm{~min}$ and the haemolysin precipitated from the supernate with $20 \%(\mathrm{w} / \mathrm{v})$ ammonium sulphate at $5{ }^{\circ} \mathrm{C}$ for $1 \mathrm{~h}$. The haemolysin was then separated by centrifugation at $6000 \mathrm{~g}$ for $30 \mathrm{~min}$ and re-dissolved in normal saline to $1 / 20$ its original volume. It 
was then centrifuged at $2500 \mathrm{~g}$ for $30 \mathrm{~min}$ and the supernate passed through a Millipore membrane filter $(450 \mathrm{~nm}$ pore diameter). These filtrates, referred to as haemolysin preparations, usually contained about 10 times more haemolysin than the extracellular fluids of the alkaline broth cultures from which they had been prepared; their titres were expressed as the dilution which haemolysed $50 \%$ of a $2 \%$ suspension of sheep erythrocytes (Smith, 1963).

Experimental animals. Eight-week-old White Swiss mice of both sexes (approx. $30 \mathrm{~g}$ ), bred at this institute, were used.

Testing haemolysin preparations for toxicity and living organisms for virulence. The toxicity of the haemolysin preparations was determined by inoculating groups of mice with twofold dilutions in normal saline into a tail vein. The virulence of live $\mathrm{Hly}^{+}$and $\mathrm{Hly}^{-}$organisms was assessed by inoculating groups of mice i.p. with three or tenfold dilutions of broth cultures in normal saline. Some of these groups were inoculated i.p. with $0 \cdot 1 \mathrm{ml}$ of $0 \cdot 2 \%(\mathrm{w} / \mathrm{v})$ $\mathrm{FeSO}_{4} 10 \mathrm{~min}$ before they were inoculated with the broth cultures (Linggood \& Ingram, 1982). The clinical signs and survival times of the mice were recorded. So were the macroscopic lesions in many that died.

Bacterial counts. The numbers of viable $E$. coli organisms in broth cultures and in heart blood, lungs and peritoneal washings of i.p. inoculated mice, were assessed by the method of Miles \& Misra using MacConkey agar (Oxoid, CM7). Lungs were first ground with sterile sand in a pestle and mortar. Peritoneal washings were obtained by rinsing the abdomen with $1 \mathrm{ml}$ of normal saline and retrieving as much of the fluid as possible.

\section{RESULTS}

\section{Inoculation of mice with haemolysin preparations}

Intravenously inoculated haemolysin preparations of the two E. coli J198 derivatives that possessed plasmid-cloned Hly determinants, WAF 107 and WAF 111 , were lethal for mice, those of WAF107, the stronger haemolysin producer (reciprocal titre 1600), being more lethal than those of WAF111 (reciprocal titre 160). For example, 16 of 20 mice inoculated with $0.1 \mathrm{ml}$ WAF 107 preparation died, compared with 9 of 20 mice inoculated with $0.5 \mathrm{ml}$ WAF 111 preparation. Similar preparations of WAF108, the non-haemolytic insertional mutant of WAF 107 and of Pla ${ }^{-}$mutants of WAF107, WAF108 and WAF111 and J198 itself, even at the highest test dose of $0.5 \mathrm{ml}$, given to groups of 20 mice, had little obvious harmful effect.

Similar results were obtained when 'wild' Hly plasmids in their natural antigenically different pig enteropathogenic E. coli hosts and in E. coli $\mathrm{K} 12$ were studied. The haemolysin preparations of these pig and $\mathrm{K} 12$ strains possessed approximately the same concentration of haemolysin and when inoculated i.v. they were about equally lethal for mice, $\mathrm{LD}_{50}$ ranging from 0.025 to $0.2 \mathrm{ml}$. A part from 9 of the 90 mice given the highest test dose $(0.5 \mathrm{ml})$ none of the mice inoculated with any of the preparations of the nine $\mathrm{Pla}^{-}$derivatives of the pig and K12 strains died. A direct correlation between haemolysin titre and lethality was noted when haemolysin preparations of E. coli B 188 containing Hly plasmids from four antigenically-different pig enteropathogens (strains P5, P102, P233 and P316) were inoculated i.v. into groups of mice. All those given $0 \cdot 1 \mathrm{ml}$ of the preparations of two of the $\mathrm{Pla}^{+}$derivatives with a haemolysin titre of 1 in 1600 died. In contrast only 2 of the 10 given this dose of a preparation of another $\mathrm{Pla}^{+}$derivative with a titre of $1 \mathrm{in} 800$ died. The titre of the preparation of the fourth derivative was 1 in 400 ; none of the mice given 0.1 or $0.2 \mathrm{ml}$ of this preparation died but 4 of the 10 given $0.5 \mathrm{ml}$ died.

Mice given the larger doses of haemolysin in all the previous experiments usually died $0.5-1 \mathrm{~h}$ after inoculation without exhibiting any characteristic clinical or pathological signs. Those given lower but still lethal doses survived longer, but rarely for more than $5 \mathrm{~h}$. The majority of them exhibited a progressively severe dyspnoea; intense haemoglobinurea was frequently observed. These signs were common to mice given haemolysin preparations of both the WAF $E$. coli strains containing the plasmid-cloned Hly determinants and E. coli strains containing the 'wild' Hly plasmids.

Inoculation of mice with cultures of $\mathrm{Hl}^{+}$and $\mathrm{Hly} y^{-}$derivatives of $\mathrm{E}$. coli J198: effect of $\mathrm{FeSO}_{4}$

When inoculated i.p., WAF107 and, to a lesser extent, WAF111, the weaker producer of haemolysin in vitro, were more virulent for mice than the Hly ${ }^{-}$derivatives of these strains and of $\mathrm{J} 198$ itself (Table 1). When $\mathrm{FeSO}_{4}$ was given i.p. before infection, the virulence of all the strains increased to about the same level. A striking observation was that survival times of mice that died following inoculation with $\mathrm{Hly}^{+}$derivatives were much shorter than those of mice that died 
Table 1. Mortality in mice inoculated i.p. with cultures of derivatives (WAF) of E. coli J198 of different plasmid constitution: effect of $\mathrm{FeSO}_{4}$

\begin{tabular}{|c|c|c|c|c|c|c|}
\hline \multirow[b]{2}{*}{$\begin{array}{l}\text { Pre-treatment } \\
\text { with } \mathrm{FeSO}_{4}^{*}\end{array}$} & \multirow[b]{2}{*}{$\begin{array}{l}\text { Derivative } \\
\text { inoculated } \dagger\end{array}$} & \multirow[b]{2}{*}{$\begin{array}{l}\text { Hly } \\
\text { status }\end{array}$} & \multicolumn{4}{|c|}{$\begin{array}{l}\text { No. of } 10 \text { mice that died after receiving } \\
10^{7} \times \text { the following no. of viable organisms }\end{array}$} \\
\hline & & & $\overparen{70}$ & 10 & 3 & 1 \\
\hline \multirow[t]{7}{*}{ No } & WAF 107 & + & 10 & 5 & 0 & 0 \\
\hline & WAF 108 & - & 0 & 0 & - & - \\
\hline & $\mathrm{Pla}-\mathrm{WAF} 107$ & - & 1 & 0 & - & - \\
\hline & $\mathrm{Pla}^{-}$WAF 108 & - & 1 & 0 & - & - \\
\hline & WAF111 & + & 7 & 0 & - & - \\
\hline & $\mathrm{Pla}^{-} \mathrm{WAF} 111$ & - & 0 & 0 & - & - \\
\hline & $\mathrm{J} 198$ & - & 1 & 0 & - & - \\
\hline \multirow[t]{7}{*}{ Yes } & WAF 107 & + & 10 & 10 & 6 & 2 \\
\hline & WAF 108 & - & 10 & 9 & 0 & 0 \\
\hline & $\mathrm{Pla}^{-} \mathrm{WAF} 107$ & - & 9 & 9 & 3 & 0 \\
\hline & Pla-WAF 108 & - & 10 & 9 & 0 & 0 \\
\hline & WAF111 & + & 10 & 10 & 2 & 0 \\
\hline & $\mathrm{Pla}^{-} \mathrm{WAF} 111$ & - & 10 & 9 & 5 & 0 \\
\hline & $\mathrm{J} 198$ & - & 10 & 10 & 4 & 0 \\
\hline
\end{tabular}

-, Not applicable.

* Where applicable, mice were given $200 \mu \mathrm{FeSO}_{4}$ i.p. $10 \mathrm{~min}$ before receiving the $E$. coli inoculum.

$\dagger \mathrm{Pla}^{-}$, plasmid-free. The plasmids of WAF107 and WAF 111 contained different cloned Hly determinants; the plasmid of WAF108 was an insertional mutant of the plasmid of WAF107.

Table 2. Survival times of mice inoculated i.p. with $3 \times 10^{8}$ viable organisms of the derivatives of E. coli $J 198$

For other details see Table 1.

No. of 20 mice that had died by the following times (h)

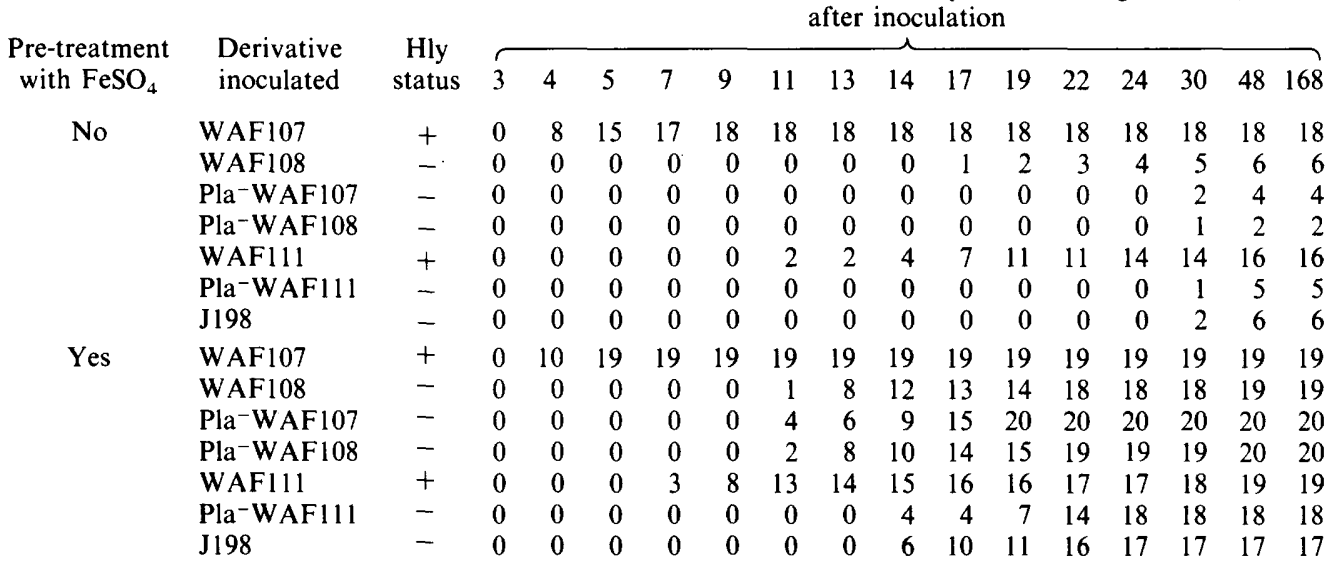

following inoculation with the $\mathrm{Hly}^{-}$derivatives. This was well illustrated in another experiment in which groups of 20 mice were inoculated with $3 \times 10^{8}$ viable organisms of the different derivatives and their survival times recorded at frequent intervals (Table 2). As far as the $\mathrm{FeSO}_{4}$-treated mice were concerned, most of those given WAF107 had died by $5 \mathrm{~h}$ after inoculation. This situation was reached in the mice given WAF111 by $11 \mathrm{~h}$ but it was not reached in the mice given the $\mathrm{Hly}^{-}$derivatives until $17 \mathrm{~h}$ or more, despite the fact that the lethality of the $\mathrm{Hly}^{+}$and $\mathrm{Hly}^{-}$derivatives for mice pre-treated with $\mathrm{FeSO}_{4}$ was about the same (Table 1).

In the above studies with live cultures of the J198 derivatives and in subsequent ones with them and with strains possessing 'wild' Hly plasmids, the clinical and pathological signs exhibited by mice inoculated with $\mathrm{Hly}^{+}$organisms resembled those previously noted in mice 
Table 3. Bacterial counts on tissues of mice inoculated i.p. with $3 \times 10^{8}$ viable organisms of the different derivatives of $E$. coli $J 198$

Five mice given each treatment were killed and the number of organisms in their peritoneal washings, lungs and blood were counted; peritoneal washings were obtained by rinsing out the abdomen with $1 \mathrm{ml}$ of normal saline. The median for each set of five results is shown. The results for five mice examined 3 min after inoculation with WAF107 were: peritoneal washings, $7 \cdot 7$; lung, $3 \cdot 3$; blood, $3 \cdot 5$.

\begin{tabular}{|c|c|c|c|c|c|c|c|c|c|}
\hline \multirow{3}{*}{$\begin{array}{l}\text { Pre-treatment } \\
\text { with } \mathrm{FeSO}_{4}\end{array}$} & \multirow{3}{*}{$\begin{array}{l}\text { Derivative } \\
\text { inoculated }\end{array}$} & \multirow{3}{*}{$\begin{array}{l}\text { Hly } \\
\text { status }\end{array}$} & \multirow{3}{*}{$\begin{array}{l}\text { Time }(\mathrm{h}) \text { after } \\
\text { inoculation* }\end{array}$} & \multicolumn{6}{|c|}{$\left.\log _{10}[\text { No. of organisms (g material) })^{-1}\right]$ in: } \\
\hline & & & & \multicolumn{2}{|c|}{$\begin{array}{c}\begin{array}{c}\text { Peritoneal } \\
\text { washings }\end{array} \\
\end{array}$} & \multicolumn{2}{|c|}{$\overbrace{\text { Lung }}^{\text {Lung }}$} & \multicolumn{2}{|c|}{ Blood } \\
\hline & & & & $3 \cdot 5$ & $13-16$ & $3 \cdot 5$ & $13-16$ & $3 \cdot 5$ & $13-16$ \\
\hline \multirow[t]{7}{*}{ No } & WAF 107 & + & & $9 \cdot 0$ & NA & $4 \cdot 8$ & NA & $4 \cdot 3$ & NA \\
\hline & WAF108 & - & & $8 \cdot 6$ & $6 \cdot 0$ & $5 \cdot 5$ & $4 \cdot 0$ & $6 \cdot 0$ & $<2 \cdot 0$ \\
\hline & Pla-WAF 107 & - & & $9 \cdot 0$ & $7 \cdot 0$ & 6.7 & $5 \cdot 6$ & $6 \cdot 8$ & $3 \cdot 7$ \\
\hline & $\mathrm{Pla}^{-}$WAF 108 & - & & $9 \cdot 0$ & $6 \cdot 4$ & $6 \cdot 2$ & 4.9 & $6 \cdot 0$ & $3 \cdot 5$ \\
\hline & WAF111 & + & & $8 \cdot 3$ & $6 \cdot 5$ & $4 \cdot 5$ & $5 \cdot 5$ & $4 \cdot 7$ & $3 \cdot 5$ \\
\hline & Pla-WAF11 & - & & 8.9 & $6 \cdot 7$ & $6 \cdot 2$ & $5 \cdot 4$ & $6 \cdot 3$ & $6 \cdot 7$ \\
\hline & J198 & - & & 8.7 & $8 \cdot 0$ & $6 \cdot 2$ & $6 \cdot 7$ & $5 \cdot 9$ & $6 \cdot 0$ \\
\hline \multirow[t]{7}{*}{ Yes } & WAF 107 & + & & $9 \cdot 0$ & NA & $4 \cdot 5$ & NA & $5 \cdot 0$ & $\mathrm{NA}$ \\
\hline & WAF 108 & - & & $9 \cdot 0$ & 9.9 & $5 \cdot 9$ & $7 \cdot 2$ & $6 \cdot 2$ & $7 \cdot 2$ \\
\hline & $\mathrm{Pla}^{-}$WAF 107 & - & & $9 \cdot 2$ & 9.9 & $6 \cdot 3$ & $7 \cdot 8$ & 6.8 & $6 \cdot 9$ \\
\hline & Pla-WAF 108 & - & & $9 \cdot 2$ & $10 \cdot 3$ & $6 \cdot 2$ & $7 \cdot 5$ & 5.9 & $7 \cdot 2$ \\
\hline & WAF 111 & + & & 8.9 & NA & $4 \cdot 0$ & $\mathrm{NA}$ & $4 \cdot 0$ & NA \\
\hline & Pla-WAF 111 & - & & $9 \cdot 2$ & $10 \cdot 0$ & $6 \cdot 2$ & $7 \cdot 3$ & $6 \cdot 3$ & $7 \cdot 3$ \\
\hline & J198 & - & & $9 \cdot 2$ & $10 \cdot 0$ & $5 \cdot 9$ & $7 \cdot 3$ & $6 \cdot 0$ & $6 \cdot 8$ \\
\hline
\end{tabular}

NA, Not applicable because mice so inoculated did not survive for this period of time.

* $3.5 \mathrm{~h}$ was the time when mice were dying having received the WAF107 derivative with or without $\mathrm{FeSO}_{4}$; 13-16 $\mathrm{h}$ was the time when mice were dying having received the $\mathrm{Hly}^{-}$derivatives with $\mathrm{FeSO}_{4}$.

inoculated with the sterile haemolysin preparations to the extent that they had severe progressive dyspnoea and many that survived for more than $5 \mathrm{~h}$ had intense haemoglobinurea. Serous pleural and peritoneal effusions were noted in some mice. These signs were not observed in mice that died following inoculation with $\mathrm{Hly}^{-}$organisms. They exhibited a progressive lethargy and ultimately became moribund and died. Their respiration was slow and shallow and towards the termination of the disease they had a pronounced ocular discharge. No macroscopic pathological lesions were noted in them at autopsy.

Numbers of organisms in tissues of mice after i.p. inoculation with cultures of different derivatives of E. coli $J 198$

Groups of mice, with or without $\mathrm{FeSO}_{4}$ pre-treatment, were inoculated i.p. with $3 \times 10^{8}$ viable organisms of different derivatives of $E$. coli $\mathrm{J} 198$. Mice from each group were examined $3.5 \mathrm{~h}$ later when those given the $\mathrm{Hly}^{+}$derivative WAF107 with or without $\mathrm{FeSO}_{4}$ were dying and 13-16 h later when those given the $\mathrm{Hly}$ - derivatives with $\mathrm{FeSO}_{4}$ or WAF111 without $\mathrm{FeSO}_{4}$ were dying (Table 3); groups not mentioned at these particular times were not gravely ill at that time. At $3.5 \mathrm{~h}$ the numbers of organisms in the peritoneal washings of the mice given WAF 107 were no higher then they were in most of the other mice; the numbers in their lungs and blood and in the lungs and blood of the mice given the other Hly ${ }^{+}$derivative WAF111 were usually 10 or more times lower than they were in the mice given the Hly ${ }^{-}$derivatives (Table 3 ). Counts on liver were not meaningful because relatively high numbers of organisms were found on liver surfaces immediately after i.p. inoculation. At $6 \mathrm{~h}$ after inoculation (data not shown), the mice given WAF111 with $\mathrm{FeSO}_{4}$ had only slightly higher numbers of organisms in their peritoneal washings, lungs and blood than did the mice near to death at $3.5 \mathrm{~h}$ after inoculation with WAF107. Counts of their peritoneal washings were no higher than those of the mice given the $\mathrm{Hly}^{-}$derivatives and $\mathrm{FeSO}_{4}$; their lung and blood counts were about 10 times lower. In general, the counts obtained at $6 \mathrm{~h}$ from groups of mice not given $\mathrm{FeSO}_{4}$, including those inoculated with 
Table 4. Survival times of groups of 10 mice pre-treated or not with $\mathrm{FeSO}_{4}$ and inoculated i.p. with forms of different strains of E. coli that possessed or did not possess 'wild' Hly plasmids

Where applicable, mice were given $200 \mu \mathrm{g}$ of $\mathrm{FeSO}_{4}$ i.p. $10 \mathrm{~min}$ before receiving the $E$. coli inoculum. Deaths were recorded at approx. hourly intervals between 1 and $32 \mathrm{~h}$ post infection. Survival time was recorded when 6 out of 10 mice from the group had died.

\begin{tabular}{|c|c|c|c|c|c|}
\hline \multirow{3}{*}{$\begin{array}{l}\text { E. coli } \\
\text { strain }\end{array}$} & \multirow{3}{*}{$\begin{array}{c}\log _{10}(\text { No. of viable } \\
\text { organisms inoculated })\end{array}$} & \multicolumn{4}{|c|}{ Survival time $(\mathrm{h})$ of mice } \\
\hline & & \multicolumn{2}{|c|}{$-\mathrm{FeSO}_{4}$} & \multicolumn{2}{|c|}{$+\mathrm{FeSO}_{4}$} \\
\hline & & $\mathrm{Hly}^{+}$form & Hly- form & $\mathrm{Hly}^{+}$form & $\mathrm{Hly}^{-}$form \\
\hline \multirow[t]{8}{*}{$\mathrm{MW}$} & $8 \cdot 5$ & 3 & 10 & 2 & 9 \\
\hline & $7 \cdot 5$ & 6 & 18 & 3 & 10 \\
\hline & 6.5 & 10 & - & 4 & 8 \\
\hline & $5 \cdot 5$ & - & - & 5 & 10 \\
\hline & $4 \cdot 5$ & - & - & 7 & 27 \\
\hline & $3 \cdot 5$ & - & - & 12 & 29 \\
\hline & $2 \cdot 5$ & - & - & 14 & 30 \\
\hline & 1.5 & - & - & 25 & 30 \\
\hline \multirow[t]{7}{*}{ P5 } & $8 \cdot 8$ & 5 & 32 & 3 & 12 \\
\hline & $8 \cdot 5$ & 6 & 28 & 3 & 12 \\
\hline & $8 \cdot 0$ & 8 & - & 3 & 17 \\
\hline & $7 \cdot 5$ & 11 & - & 4 & 17 \\
\hline & $7 \cdot 0$ & - & - & 4 & 18 \\
\hline & $6 \cdot 0$ & - & - & 11 & 20 \\
\hline & $5 \cdot 0$ & - & - & - & - \\
\hline \multirow[t]{4}{*}{ H209 } & $8 \cdot 8$ & 5 & 20 & 3 & 10 \\
\hline & $8 \cdot 5$ & 6 & - & 4 & 20 \\
\hline & $8 \cdot 0$ & - & - & 5 & 23 \\
\hline & $7 \cdot 5$ & - & - & - & - \\
\hline
\end{tabular}

-, Few or no deaths occurred in these groups.

WAF111, were lower than counts from the corresponding groups at $3.5 \mathrm{~h}$. When mice given the $\mathrm{Hly}^{-}$derivatives with $\mathrm{FeSO}_{4}$ were nearing death at 13-16 h after inoculation, the numbers of organisms in their peritoneal washings were about 10 times higher than the numbers in the peritoneal washings of the mice dying $3.5 \mathrm{~h}$ after inoculation with the $\mathrm{Hly}^{+}$derivative WAF107; the numbers in their lungs and blood were about 1000 times higher than the numbers in those tissues of the latter mice. The numbers of organisms at this time in the tissues of the mice given the $\mathrm{Hly}^{-}$derivatives without $\mathrm{FeSO}_{4}$ were much lower. So were the numbers in the mice given the $\mathrm{Hly}^{+}$derivative WAF111 without $\mathrm{FeSO}_{4}$, but these mice were dying whereas those given the $\mathrm{Hly}^{-}$derivatives without $\mathrm{FeSO}_{4}$ appeared normal.

Inoculation of mice with cultures of E. coli strains possessing or not possessing 'wild' Hly plasmids

The median mortality in 15 groups of 12 mice inoculated i.p. with $3 \times 10^{8}$ viable organisms of $E$. coli strain $\mathrm{H} 209$, to which the Hly plasmids of 15 epidemiologically unrelated strains of pig enteropathogenic $E$. coli belonging to seven different serotypes had been transferred, was 11 (range 7-12); all except 24 of these 162 mice died within $6 \mathrm{~h}$ of inoculation. By contrast, only three mice died in a group of 12 given the same dose of H209. One died 8-18 h and the other two died $18-24 \mathrm{~h}$ after inoculation.

Different doses of cultures of E. coli $\mathrm{H} 209$ and of the human invasive strain MW, of derivatives of these two strains to which the Hly plasmid of the pig enteropathogenic P102 had been transferred, of the pig enteropathogen $\mathrm{P} 5$ and of an $\mathrm{Hly}^{-}$derivative of it, were inoculated i.p. into groups of 10 mice. The $\mathrm{Hly}^{+}$form was more lethal than the $\mathrm{Hly}^{-}$form by a factor of about 3 in the case of $\mathrm{H} 209$ and about 10 in the case of P5; there was little difference in lethality between the two forms of $\mathrm{MW}$. In mice pre-treated with $\mathrm{FeSO}_{4}$, the lethality of the $\mathrm{Hly}^{+}$and $\mathrm{Hly}^{-}$forms of each strain was about the same; it was greater than in the mice not given $\mathrm{FeSO}_{4}$, especially in the case of MW and P5. As in the studies with the derivatives of E. coli $\mathrm{J} 198$, the 
Table 5. Counts on tissues of mice when near to death having been inoculated i.p. with different doses of $\mathrm{Hly}^{+}$and $\mathrm{Hly}^{-}$forms of E. coli $\mathrm{MW}$

Five mice given each treatment were killed and the numbers of MW organisms in peritoneal washings, lung and blood counted; the median for each set of counts is shown.

\begin{tabular}{|c|c|c|c|c|c|c|}
\hline \multirow[b]{2}{*}{$\begin{array}{l}\text { Pre-treatment } \\
\text { with } \mathrm{FeSO}_{4}\end{array}$} & \multirow[b]{2}{*}{$\begin{array}{l}\log _{10}(\text { No. of viable } \\
\text { organisms inoculated })\end{array}$} & \multirow[b]{2}{*}{$\begin{array}{l}\text { Hly } \\
\text { status }\end{array}$} & \multirow[b]{2}{*}{$\begin{array}{l}\text { Survival time } \\
\text { (h) of mice* }\end{array}$} & \multicolumn{3}{|c|}{$\begin{array}{c}\left.\log _{10}[\text { No. of organisms (g material })^{-1}\right] \\
\text { in } \dagger:\end{array}$} \\
\hline & & & & $\begin{array}{c}\text { Peritoneal } \\
\text { washings }\end{array}$ & Lung & Blood \\
\hline \multirow[t]{6}{*}{ No } & $8 \cdot 5$ & + & $2 \cdot 5$ & $8 \cdot 3(8 \cdot 5)$ & $7 \cdot 0(7 \cdot 0)$ & $7 \cdot 3(7 \cdot 6)$ \\
\hline & & - & $9 \cdot 0$ & $9 \cdot 4$ & $8 \cdot 8$ & $9 \cdot 2$ \\
\hline & $7 \cdot 5$ & + & $4 \cdot 0$ & $8.0(8.0)$ & $7 \cdot 4(6 \cdot 4)$ & $7 \cdot 5(7 \cdot 2)$ \\
\hline & & - & 11.0 & $9 \cdot 5$ & $8 \cdot 5$ & $8 \cdot 6$ \\
\hline & $6 \cdot 5$ & + & $7 \cdot 3$ & $8 \cdot 3(8 \cdot 0)$ & $6.9(6.0)$ & $7 \cdot 3(6 \cdot 5)$ \\
\hline & & - & $17 \cdot 5$ & $10 \cdot 0$ & 9.0 & 8.6 \\
\hline \multirow[t]{8}{*}{ Yes } & $8 \cdot 5$ & + & $2 \cdot 0$ & $8.8(8.5)$ & $7 \cdot 0(7 \cdot 4)$ & $7 \cdot 3(8 \cdot 0)$ \\
\hline & & - & $7 \cdot 5$ & 9.9 & 8.8 & $9 \cdot 0$ \\
\hline & 6.5 & + & $4 \cdot 5$ & $8 \cdot 3(7 \cdot 3)$ & $7 \cdot 0(6 \cdot 6)$ & $7 \cdot 0(6 \cdot 6)$ \\
\hline & & - & $9 \cdot 5$ & 9.9 & 8.9 & $9 \cdot 0$ \\
\hline & $4 \cdot 5$ & + & 10.0 & $8.8(9.7)$ & $6 \cdot 0(7 \cdot 0)$ & $6.3(6.4)$ \\
\hline & & - & $17 \cdot 0$ & $10 \cdot 0$ & $9 \cdot 0$ & $8 \cdot 0$ \\
\hline & $2 \cdot 5$ & + & $12 \cdot 5$ & $8.6(9.5)$ & $6 \cdot 3(5 \cdot 6)$ & $6.0(5 \cdot 7)$ \\
\hline & & - & $22 \cdot 0$ & $10 \cdot 3$ & $9 \cdot 0$ & $7 \cdot 8$ \\
\hline
\end{tabular}

* Survival times recorded as in Table 4.

+ The figures in parentheses are the results for a group of five mice identically treated except that they were given the $\mathrm{Hly}^{-}$form and examined at the stated time rather than when they were near to death.

disease was more acute in the mice inoculated with the $\mathrm{Hly}^{+}$forms than in the mice inoculated with the corresponding $\mathrm{Hly}^{-}$forms, the survival times of the former being much shorter than those of the latter (Table 4).

Numbers of organisms in tissues of mice near death following i.p. inoculation with E. coli $M W$ or its $\mathrm{Hly}^{+}$derivative

Irrespective of whether or not they had been pre-treated with $\mathrm{FeSO}_{4}$, the numbers of organisms in the peritoneal washings, lungs and blood of mice near death following inoculation with different doses of the $\mathrm{Hly}^{+}$derivative of $E$. coli $\mathrm{MW}$ were at least 10 times lower than they were in mice near death following i.p. inoculation with similar doses of the Hly ${ }^{-} \mathrm{MW}$ (Table 5). When the mice given any particular dose of the $\mathrm{Hly}^{+}$form were near death, the corresponding group given the $\mathrm{Hly}^{-}$form looked reasonably healthy. Yet, in those pre-treated with $\mathrm{FeSO}_{4}$, the numbers of organisms in the peritoneal washings, lungs and blood of the $\mathrm{Hly}^{-}$group at that time were usually as high as they were in the $\mathrm{Hly}^{+}$group. This was also the case for mice not pretreated with $\mathrm{FeSO}_{4}$ in the case of the peritoneal washings and of the lungs and blood of those given the highest inoculation dose; the numbers of organisms in the lungs and blood of those given the lower doses were somewhat higher than they were in the mice given the Hly- form.

\section{DISCUSSION}

The experiments with bacteria-free preparations of the WAF set of strains, differing only in respect of whether or not they contained functioning genes for haemolysin production, established the validity of the findings of earlier studies (Smith \& Halls, 1967) and of the present study employing 'wild' Hly plasmids, i.e. that haemolysin is toxic for mice to the extent that it may be lethal in high dosage. Mice that died soon after inoculation did not exhibit any evidence of haemoglobinurea, frequently noted in animals that succumbed later, indicating that mass destruction of erythrocytes was not the main manner whereby haemolysin exerted its lethal action. 
In assessing the role of haemolysin in the disease produced by i.p. inoculation of mice with living organisms, the following observations have also to be taken into consideration. (1) Mice given the $\mathrm{Hly}^{+}$WAF strains and the strains possessing 'wild' Hly plasmids died much sooner than the mice given the corresponding $\mathrm{Hly}^{-}$forms of these strains. This was so even in mice that had been pre-treated with $\mathrm{FeSO}_{4}$, a procedure which rendered them equally susceptible to the lethal activity of both the $\mathrm{Hly}^{+}$and $\mathrm{Hly}^{-}$forms of a strain. (2) Mice dying from infection with the $\mathrm{Hly}^{+}$forms had much lower numbers of organisms in their tissues than did mice dying from infection with the corresponding $\mathrm{Hly}^{-}$forms. The numbers of organisms in the tissues of $\mathrm{FeSO}_{4}{ }^{-}$ treated mice dying from infection with $\mathrm{Hly}^{+}$forms were no higher than they were at that particular time in mice given the corresponding Hly- forms; those in the lungs and blood were often lower. Yet the latter mice appeared reasonably healthy. The numbers of organisms in their tissues increased to a much greater extent before they became gravely ill. (3) Not only were bacteria-free preparations of WAF111 [which Welch \& Falkow (1984) and ourselves found to produce much less haemolysin in vitro than the other $\mathrm{Hly}^{+}$derivative of J198, WAF107] less toxic for mice than similar preparations of WAF107, but mice inoculated with live cultures of WAF111 were less susceptible to fatal infection and survived for much longer than mice inoculated with WAF107. (4) The clinical and pathological signs in mice infected with Hly ${ }^{+}$ organisms resembled those in mice given haemolysin preparations, the haemoglobinurea often noted in mice given the $\mathrm{Hly}^{+}$organisms, indicating that the organisms were producing haemolysin in vivo; these signs were not noted in mice given $\mathrm{Hly}^{-}$organisms. These observations are compatible with the following hypothesis. After inoculation, $\mathrm{Hly}^{+}$organisms multiply and produce haemolysin. When sufficient has been liberated the host dies. Haemolysin is the most toxic product of the organisms. Consequently, inoculated $\mathrm{Hly}^{-}$organisms have to multiply to a much greater extent than the $\mathrm{Hly}^{+}$organisms before they cause the death of the host. Whether or not haemolysin also increased the severity of the disease in our mouse model by making iron more readily available to the invading organisms by lysing erythrocytes, as propounded by Linggood \& Ingram (1982), is not known - our experiments were not designed to throw light on this aspect of the infection. There was no evidence that it was so in the experiments we performed with the WAF derivatives or with the highest dose of MW. However, in the mice given the two lower doses of $\mathrm{MW}$ without $\mathrm{FeSO}_{4}$ and examined when those given the $\mathrm{Hly}^{+}$form were dying, the numbers of organisms in the lungs and blood, but not the peritoneal washings, of those given the $\mathrm{Hly}^{+}$form did tend to be higher than in those given the corresponding dose of the $\mathrm{Hly}^{-}$form.

We are grateful to Mrs Kathleen Shaw and Miss Teresa Winstanley for their capable technical help. Our thanks are also due to Professor P. M. Biggs, Mrs Shirley Pilcher, Miss Betty Royston and Mr Peter Townsend.

\section{REFERENCES}

van den Bosch, J. F., Postma, P., de Graaff, J. \& MAClaReN, D. M. (1981). Haemolysis by urinary Escherichia coli and virulence in mice. Journal of Medical Microbiology 14, 321-331.

VAN DEN BoSCH, J. F., EMÖDY, L. \& KETYI, I. (1982). Virulence of haemolytic strains of Escherichia coli in various animal models. FEMS Microbiology Letters 13, $427 \cdot 430$.

Cavalieri, S. J. \& Snyder, I. S. (1982a). Cytotoxic activity of partially purified Escherichia coli alphahaemolysin. Journal of Medical Microbiology 15, 11 21 .

Cavalieri, S. J. \& Snyder, I. S. (1982b). Effect of Escherichia coli alpha-haemolysin on human peripheral leukocyte viability in vitro. Infection and Immunity 36, 455-461.

Cavalieri, S. J. \& SNyder, I. S. (1982c). Effect of Escherichia coli alpha-haemolysin on human peripheral leukocyte function in vitro. Infection and Immunity 37, 966-974.
Chaturvedi, U. C.. Mathur, A., Khan, A: M. \& Mehrotra, R. M. L. (1969). Cytotoxicity of filtrates of haemolytic Escherichia coli. Journal of Medical Microhiology 2, 211-218.

Cooke, E. M. \& Ewins, S. P. (1975). Properties of strains of Escherichia coli isolated from a variety of sources. Journal of Medical Microhiology 8, $107-$ 111.

Emödy, L., Pál, T., Safonova, N. V., Kuch, B. \& Golutva, N. K. (1980). Alpha-haemolysin: an additive virulence factor in Escherichia coli. Acta microbiologica Academiae scientiarum hungaricae 27, 333342.

Fried, F. A., Vermeulen, C. W., Ginsburg, M. J. \& CONE, C. M. (1971). Etiology of pyelonephritis: further evidence associating the production of experimental pyelonephritis with haemolysis in Escherichia coli. Journal of Urology 106, 351-354.

Gadeberg, O. V., Orskov, I. \& Rhodes, J. M. (1983). Cytotoxic effect of alpha-haemolytic strain on 
human blood monocytes and granulocytes in vitro. Infection and Immunity 41, 358-364.

Goebel, W. \& HedGPETH, J. (1982). Cloning and functional characterization of the plasmid-encoded haemolysin determinant of Escherichia coli. Journal of Bacteriology 151, 1290-1298.

Hacker, J., Hughes, C., Hof, H. \& Goebel, W. (1983). Cloned haemolysin genes from Escherichia coli that cause urinary tract infection determine different levels of toxicity in mice. Infection and Immunity 42, 57-63.

KÉTYi, I. EMÖdy, L., Kontrohr, T., Vertényi, A., Pácsa, S., Avdeeva, T. A., Safonova, N. V. \& Golutova, N. K. (1978). Mouse lung oedema caused by a toxic substance of Escherichia coli strains. Acta microbiologica Academiae scientiarum hungaricae 25, 307-317.

LingGoOD, M. A. \& INGRAM, P. L. (1982). The role of alpha-haemolysin in the virulence of Escherichia coli for mice. Journal of Medical Microbiology 15, 23-30.

Smith, H. Williams (1963). The haemolysins of Escherichia coli. Journal of Pathology and Bacteriology 85, 197-211.

Smith, H. Williams \& Halls, S. (1967). The transmissible nature of the genetic factor in Escherichia coli that controls haemolysin production. Journal of General Microbiology 47, 153-161.

Smith, H. Williams \& Huggins, M. B. (1980). The association of the $\mathrm{O} 18, \mathrm{KI}$ and $\mathrm{H} 7$ antigens and the Colv plasmid of a strain of Escherichia coli with its virulence and immunogenicity. Journal of General Microbiology 121, 387-400.

Smith, H. Williams \& Linggood, M. A. (1971). Observations on the pathogenic properties of the K88, Hly and Ent plasmids of Escherichia coli with particular reference to porcine diarrhoea. Journal of Medical Microbiology 4, 467-485.

WAALWIJK, C. \& DE GRAAFF, J. (1983). Inactivation of haemolysin production in Escherichia coli by transposon insertion results in loss of virulence. Antonie van Leeuwenhoek, Journal of Microbiology and Serolog.' 49, 23-30.

Waalwijk, C., van den Bosch, J. F., Maclaren, D. M. \& DE GraAFF, J. F. (1982). Haemolysin plasmid coding for the virulence of a nephropathogenic Escherichia coli strain. Infection and Immunity 35, 32-37.

WaAlwiJk, C., Maclaren, D. M. \& de GraAfF, J. (1983). In vivo function of haemolysin in the nephropathogenicity of Escherichia coli. Infection and Immunity 42, 245-249.

WelCh, R. A. \& Falkow, S. (1984). Characterization of Escherichia coli haemolysins conferring quantitative differences in virulence. Infection and Immunity 43, $156-160$.

Welch, R. A., Dellinger, E. P., Minshew, B. \& Falkow, S. (1981). Haemolysin contributes to virulence of extra-intestinal $E$. coli infections. Nature, London 293, 665-667. 